\title{
Tugas Akhir dan Faktor Stres Mahasiswa
}

\section{Sri Suhandiah ${ }^{1}$, Ayuningtyas ${ }^{2}$, Pantjawati Sudarmaningtyas ${ }^{3}$}

DOI: https://doi.org/10.36339/jaspt.v5i1.424

\begin{abstract}
Abstrak
Mahasiswa yang sedang menyusun tugas akhir merupakan individu yang rentan mengalami stres. Mahasiswa yang mengalami stres cenderung mengalami gangguan dalam fungsi fisik, emosi, kognitif, dan tingkah laku yang dapat berimbas pada waktu penyelesaian. Penelitian ini bertujuan untuk mengidentifikasi faktor-faktor yang mempengaruhi stres mahasiswa dalam menyusun Tugas Akhir. Sampel diambil dari 108 mahasiswa yang sedang mengambil mata kuliah Tugas Akhir. Hasil analisis dengan metode analisis jalur menunjukkan bahwa faktor sosial, keluarga, dosen, dan motivasi secara bersama-sama tidak memiliki pengaruh terhadap stres mahasiswa yang sedang menyusun Tugas Akhir. Meskipun secara parsial faktor keluarga dan dosen menjadi faktor yang secara signifikan mempengaruhi motivasi mahasiswa, tetapi hanya faktor keluarga yang memberikan pengaruh terhadap stres mahasiswa. Dukungan keluarga akan meningkatkan motivasi dan semakin termotivasi maka tingkat stres mahasiswa akan menurun.
\end{abstract}

Kata kunci: faktor stres, mahasiswa tugas akhir, motivasi individu

\begin{abstract}
Students who are preparing their final projects are individuals who are susceptible to stress. Students who experience stress tend to experience disturbances in physical, emotional, cognitive, and behavioural functions that can impact the completion of the final project. This study aims to identify the factors that influence student stress in preparing the Final Project. Samples were taken from 108 students who were taking Final Projects. The result of the analysis using the path analysis method shows that social factors, family, lecturers, and motivation all together do not influence the stress of students who are preparing the Final Project. Although, family and lecturer are factors that partially significantly influence student motivation. The family is the only factor that influences student stress. Family support will increase motivation. The more their family motivates, the stress level of students will decrease.
\end{abstract}

Keywords: individual motivation, stress factors, student final project

\section{PENDAHULUAN}

Depresi, kecemasan, dan masalah perilaku adalah beberapa dari banyak masalah yang dilaporkan pada siswa dengan tekanan akademik tinggi (Deb et al., 2015). Insiden depresi juga ditemukan di antara remaja yang stres karena dikaitkan dengan ketidakmampuan untuk berkonsentrasi, takut gagal, evaluasi negatif masa depan

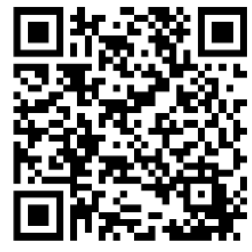

Fakultas Ekonomi dan Bisnis, Universitas Dinamika, Jl. Raya Kedung Baruk 98 Surabaya, Jawa Timur Indonesia

Fakultas Teknologi dan Informatika, Universitas Dinamika, Jl. Raya Kedung Baruk 98 Surabaya, Jawa Timur, Indonesia

Fakultas Teknologi dan Informatika, Universitas Dinamika, Jl. Raya Kedung Baruk 98 Surabaya, Jawa Timur, Indonesia

Email of Corresponding Author : tyas@dinamika.ac.id 
(Busari, 2012). Remaja juga dilaporkan terlibat dalam berbagai perilaku berisiko seperti peningkatan konsumsi alkohol dan obat-obatan, aktivitas seksual, aktivitas fisik, buruk pola makan dan tidur (Bennett \& Holloway, 2014; The American College Health Association, 2009). Menurut statistik yang diterbitkan oleh National Biro Catatan Kejahatan, ada satu siswa setiap jam itu melakukan bunuh diri, 1,8\% siswa yang bunuh diri karena gagal dalam ujian dan kenaikan $80 \%$ dalam tingkat bunuh diri selama jangka waktu satu tahun (Saha, 2017).

Stresor atau penyebab stres pada mahasiswa dapat bersumber dari kehidupan akademiknya, terutama dari tuntutan eksternal dan tuntutan dari harapannya sendiri. Penyebab stres yang berasal dari dalam diri individu, misalnya harga diri dan konsep diri. Timbulnya stres tergantung bagaimana individu menilai dan menginterpretasikan suatu kejadian secara kognitif. Penilaian secara kognitif adalah istilah untuk menggambarkan interpretasi individu terhadap kejadian-kejadian dalam hidup mereka sebagai sesuatu yang berbahaya, mengancam, dan keyakinan mereka dalam menghadapi kejadian tersebut secara efektif. menyampaikan bahwa lingkungan merupakan salah satu sumber stres pada individu.

Stres pada dasarnya tidak selalu berdampak negatif. Stres dapat bersifat merangsang individu untuk bertingkah laku positif. Stres yang berdampak positif biasa disebut dengan eustress dan stres yang berdampak negatif biasa disebut dengan distress (Kupriyanov \& Zhdanov, 2014) Menurut penelitian tersebut stres dapat dikonsepkan pada beberapa cara, yaitu: stress sebagai stimulus, stress sebagai respon, dan stress sebagai proses yang melibatkan stressor dan strain. (Anoraga, 2006) menyatakan bahwa stres yang tidak dapat teratasi menimbulkan beberapa gejala yaitu gejala fisik, psikis, dan sosial. Gejala fisik antara lain meliputi sakit kepala, keluar keringat dingin, jantung berdebar, muntah, napsu makan menurun. Gejala psikis antara lain rasa cemas, was-was, pelupa, susah berkonsentrasi, gelisah, keinginan bunuh diri. Gejala sosial antara lain meliputi mudah bertengkar, menarik diri dari pergaulan sosial, dan merusak lingkungan.

Stres yang dialami oleh mahasiswa dapat memiliki beberapa tingkatan. Akan tetapi tingkat stres yang rendah belum tentu menjadikan mahasiswa akan berkinerja lebih baik. Dalam keadaan ini mereka menganggap bahwa tugas yang diberikan tidak menantang dan juga mudah bosan (Uchil, 2017). Beberapa faktor yang menjadi penyebab stres mahasiswa diantaranya adalah masalah dalam manajemen keuangan, perubahan dalam suasana hidup, kesulitan mengelola pribadi dan kehidupan akademik (Biron C, Brun JP, 2008; Chernomas \& Shapiro, 2013; Goff, 2011; Jimenez et al., 2010; Moscaritolo, 2009). Harapan Orang tua dan institusi yang memberikan tekanan terhadap kegagalan yang berdampak harga diri dan kepercayaan diri juga dilaporkan sebagai penyebab stres (Ang \& Huan, 2006).

Mahasiswa yang sedang menyusun skripsi/tugas akhir juga merupakan individu yang rentan mengalami stres. Di universitas, skripsi/tugas akhir merupakan mata kuliah yang memiliki beban kredit semester sebesar 6 sks. Setiap mahasiswa yang mengambil mata kuliah tugas akhir, akan didampingi sekurang-kurang satu orang dosen pembimbing dan

JAS-PT

JURNAL ANALISIS SISTEM PENDIDIKAN TINGGI ISSN $2580-5339$ eISSN $2620-5718$ Volume 5 Nomor 1

JULI 2021

Hal 65 - 74

DOSEN INDONESIA SEMESTA sebanyak-banyaknya dua orang dosen pembimbing. Dalam upaya menyelesaikan tugas akhirnya, mahasiswa seringkali dihadapkan pada beberapa kendala, yang mungkin dapat menurunkan motivasi dan meningkatkan stres sehingga mahasiswa tidak dapat Iulus dalam satu semester. Menurut Gunawati et al. (2010), salah satu faktor yang dapat menyebabkan stres pada mahasiswa yang menyusun skripsi/tugas akhir adalah hubungan interpersonal yang kurang harmonis dengan dosen pembimbing. Sementara studi (Kumar et al., 2019) menyampaikan bahwa stres mahasiswa tingkat akhir antara 
lain disebabkan oleh tekanan untuk lulus ujian dan tekanan untuk memenuhi harapan keluarga. Temuan ini senada dengan yang disampaikan oleh Subramani \& Venkatachalam (2019) bahwa ketika mahasiswa tidak dapat mencapai harapan orang tua mereka, maka akan menimbulkan tekanan dan dampak pada prestasi akademiknya. Selain itu stres yang dialami mahasiswa juga tidak membedakan gender. Mahasiswa laki-laki atau pun perempuan tidak ada perbedaan yang signifikan dalam hal factor-faktor penyebab stres mahasiswa (Dada et al., 2019).

Berdasarkan fenomena dan peneltian sebelumnya, penelitian ini bertujuan untuk mengidentifikasi faktor-faktor yang mempengaruhi stres mahasiswa dalam mengerjakan tugas akhir. Penelitian ini akan melengkapi penelitian sebelumnya terkait mahasiswa yang sedang mengerjakan tugas akhir. Hasil ini akan membantu perguruan tinggi untuk menemukan sumber stres dimana hal ini akan memudahkan perguruan tinggi dalam menentukan strategi pembimbingan bagi mahasiswa Selain itu, hasil penelitian diharapkan akan memberikan kontribusi pada perguruan tinggi umumnya dan program studi khususnya untuk meningkatkan waktu kelulusan mahasiswa.

\section{METODE PENELITIAN}

Penelitian ini merupakan penelitian eksplanatori menggunakan metode kuantitatif, yang akan menjelaskan hubungan antar variabel melalui pengujian hipotesis, serta melakukan eksplanasi terhadap faktor-faktor yang mempengaruhi stres yang dialami oleh mahasiswa yang mengambil mata kuliah Tugas Akhir.

Populasi penelitian ini adalah mahasiswa Strata Satu (S1) dari tujuh program studi yang berasal dari fakultas teknik dan fakultas ekonomi dan bisnis di salah satu universitas yang ada di Surabaya. Sampel yang digunakan dalam penelitian ini adalah sampel jenuh, dengan jumlah total mahasiswa yang sedang melaksanakan Tugas Akhir pada tahun akademik Genap 2018/2019 adalah sebanyak 288 mahasiswa.

Kuesioner yang digunakan sebagai instrumen penelitian adalah bersifat tertutup. Kuesioner ini terdiri atas 44 item pertanyaan yang terkait dengan faktor sosial, keluarga, dosen, motivasi, dan juga stres. Skala pengukuran menggunakan model semantik diferensial dengan susunan nilai 1 di posisi paling kiri untuk menyatakan derajat rendah dan semakin ke kanan memiliki derajad yang lebih tinggi. Penyebaran kuesioner dilakukan secara langsung kepada seluruh responden yang dituju. Dari 288 kuesioner yang disebarkan, sebanyak 150 kuesioner diterima kembali, dan 108 kuesioner dapat diolah karena 42 kuesioner lainnya tidak diisi secara lengkap.

Data yang telah masuk kemudian diolah dan dianalisis dengan menggunakan teknik analisis jalur. Analisis jalur merupakan teknik yang digunakan dalam menganalisis hubungan sebab akibat yang tejadi pada regresi berganda, baik ketika variabel bebasnya

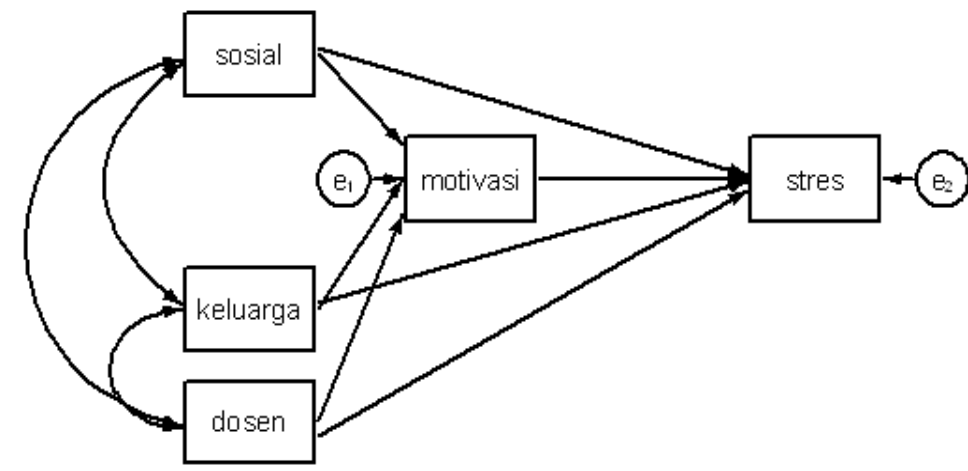

Gambar 1 Kerangka Konsep Penelitiaan

JAS-PT

URNAL ANALSIS SISTEM PENDIDIKAN TINGG

ISSN $2580-5339$

eISSN $2620-5718$

Volume 5

Nomor

JULI 2021

Hal 65 - 74

DOSEN INDONESIA SEMESTA 
mempengaruhi variabel tergantung secara langsung maupun tidak langsung (Enderlein, 1994). Adapun model kerangka konsep penelitian dapat digambarkan pada Gambar 1 sebagai berikut.

Dengan model kerangka penelitian seperti nampak pada Gambar 1, maka kerangka analisis jalur dapat diterangkan sebagai berikut:

1. Terdapat tiga variabel bebas (variabel eksogen) yaitu sosial ( $x 1)$, keluarga ( $x 2)$, Dosen (x3)

2. Terdapat dua variabel terikat (variabel endogen) yaitu motivasi (y1), dan stres (y2)

3. Ada dua substruktur dalam model empirik analisis jalur. Substruktur pertama adalah pengaruh variabel sosial, keluarga, dan dosen terhadap motivasi dan substruktur kedua adalah pengaruh variabel sosial, keluarga, dan dosen melalui motivasi terhadap stres mahasiswa.

4. Satu variabel endogen (y1) menjadi penyebab variabel endogen lainnya (y2).

Persamaan struktural untuk model analisis jalur di atas adalah sebagai berikut:

$$
\begin{aligned}
& Y 1=\rho_{y 1 x 1} X_{1}+\rho_{y 1 x_{2}} X_{2}+\rho_{y 1 x_{3}} X_{3}+e_{1} \\
& Y_{2}=\rho_{y 2 x 1} X_{1}+\rho_{y 2 x_{2}} X_{2}+\rho_{y 2 x_{3}} X_{3}+\rho_{y 2 y i} Y_{1}+e_{2}
\end{aligned}
$$

Adapun hipotesis penelitian ini adalah:

H1.1 : Faktor sosial berpengaruh positif terhadap motivasi mahasiswa dalam menyusun tugas akhir

H1.2 : Faktor keluarga berpengaruh positif terhadap motivasi mahasiswa dalam menyusun tugas akhir

H1.3 : Faktor dosen berpengaruh positif terhadap motivasi mahasiswa dalam menyusun tugas akhir

H1.4 : Faktor motivasi berpengaruh positif terhadap stres mahasiswa dalam menyusun tugas akhir

H1.5 : Faktor sosial berpengaruh positif terhadap stres mahasiswa dalam menyusun tugas akhir yang dimediasi oleh motivasi

H1.6 : Faktor keluarga berpengaruh positif terhadap stres mahasiswa dalam menyusun tugas akhir yang dimediasi oleh motivasi

H1.7 Faktor dosen berpengaruh positif terhadap stres mahasiswa dalam menyusun tugas akhir yang dimediasi oleh motivasi

\section{HASIL DAN PEMBAHASAN}

\section{Uji Validitas dan Reliabilitas}

Pengujian validitas Pengujian validitas dilakukan pada masing-masing variabel dengan menggunakan software SPSS. Dengan $r$ tabel dengan $N=108$ sebesar 0,187 pada taraf signifikansi 0,05 diperoleh hasil pengujian yang bersifat valid pada semua item kuesioner. Sementara untuk uji reliabilitas, hasil uji reliabilitas yang dilakukan dengan metode

JAS-PT

ALISIS SISTEM PENDIDIKAN TINGG

ISSN $2580-5339$

eISSN $2620-5718$

Volume 5

Nomor 1

JULI 2021

Hal $65-74$

DOSEN INDONESIA SEMESTA

\section{Hasil Estimasi Model Substruktur 1}

Setelah dilakukan pengolahan data, maka hasil estimasi substruktur 1 sebagaimana model kerangka berpikir dapat disampaikan sebagai berikut.

\section{a. Pengaruh sosial, keluarga, dan dosen, secara gabungan terhadap motivasi mahasiswa.}


1) Korelasi antara variabel Sosial dan variabel Keluarga.Berdasarkan perhitungan $d$ iperoleh angka korelasi antara variabel Sosial dan variabel Keluarga adalah sebesar 0,446 . Hal ini berarti hubungan antara variabel Sosial dan variabel Keluarga bersifat searah tetapi lemah. Sedangkan korelasi antara variabel Sosial dan variabel Keluarga adalah signifikan.

2) Korelasi antara variabel variabel Keluarga dan variabel Dosen. Berdasarkan perhitungan diperoleh angka korelasi antara variabel Sosial dan variabel Keluarga adalah sebesar 0,415. Hal ini berarti hubungan antara variabel Keluarga dan variabel Dosen bersifat searah tetapi lemah.. Selain itu, korelasi antara variabel Keluarga dan variabel Dosen adalah signifikan. Hal ini terlihat bahwa angka signifikansi (sig.) sebesar $5.21>1,96$

3) Korelasi antara variabel Sosial dan variabel Dosen. Berdasarkan perhitungan diperoleh angka korelasi antara variabel Sosial dan variabel Dosen adalah sebesar 0,299 . Hal ini berarti hubungan antara variabel Sosial dan variabel Dosen bersifat lemah tetapi searah. Selain itu, Korelasi antara variabel Sosial dan variabel Dosen bersifat signifikan. Hal ini terlihat bahwa angka signifikansi (sig.) sebesar 3,42 >1,96

\section{Hasil Estimasi Model Substruktur 2}

a. Pengaruh motivasi, sosial, keluarga, dan dosen, secara gabungan terhadap stres mahasiswa.

Tabel 4. Hasil Estimasi Substruktur 2 secara gabungan

\begin{tabular}{|c|c|c|c|c|c|}
\hline Source & SS & df & MS & \multicolumn{2}{|l|}{ Number of obs $=$} \\
\hline Model & 27.9062 & 4 & 6.977 & $F(3,104)$ & $=1.62$ \\
\hline & & & & Prob $>F$ & $=0.1757$ \\
\hline Residual & 444.5374 & 103 & 4.316 & R-squared & $=0.0591$ \\
\hline Total & 472.4435 & 107 & 4.415 & Root MSE & $=2.0775$ \\
\hline
\end{tabular}

Berdasarkan hasil estimasi pada Tabel 4, diketahui bahwa koefisien determinasi pada Tabel tersebut menunjukkan nilai $r^{2}=0,059$. Hal ini menunjukkan bahwa pengaruh perubahan secara bersama-sama variabel Sosial, Keluarga, Dosen, dan Motivasi terhadap Stres adalah sebesar 5\%, dan 95\% berasal dari faktor-faktor lain di luar model ini. Dengan Prob > F yang lebih besar dari 0,05 maka dapat disampaikan pula bahwa Motivasi, Sosial, Keluarga, dan Dosen, secara gabungan tidak memiliki pengaruh yang signifikan terhadap Stres.

\section{b. Pengaruh motivasi, sosial, keluarga, dan dosen, secara parsial terhadap stres mahasiswa.}

Tabel 5. Hasil Estimasi Substruktur 1 secara parsial

JAS-PT

JURNAL ANALISIS SISTEM PENDIDIKAN TINGG ISSN $2580-5339$ eISSN $2620-5718$

Volume 5

Nomor 1

JULI 2021

Hal 65 - 74

\begin{tabular}{lcccc}
\hline \multicolumn{1}{c}{ Path } & $\begin{array}{c}\text { Loading } \\
\text { factor }\end{array}$ & $\begin{array}{c}\text { Standardized } \\
\text { path coefficient }\end{array}$ & $\begin{array}{c}\text { Koefisien } \\
\text { Determinasi (r2) }\end{array}$ & Z-Score \\
\hline Motivasi $\rightarrow$ stress & 0,03 & 0,02 & 0,00 & 0,21 \\
\hline Sosial $\rightarrow$ stres & 0,08 & 0,06 & 0,00 & 0,61 \\
\hline Keluarga $\rightarrow$ stress & $-0,32$ & $-0,25$ & 0,06 & $-2,03$ \\
\hline Dosen $\rightarrow$ Stres & $-0,08$ & $-0,06$ & 0,00 & $-0,61$ \\
\hline
\end{tabular}

Dari Tabel 5 , hasil estimasi terlihat bahwa nilai Z-Score variabel Motivasi terhadap Stres adalah <1,96; nilai Z-Score variabel Sosial terhadap Stres adalah <1,96; nilai Z-Score variabel Keluarga terhadap Stres adalah $>1,96$ dan bernilai negatif.; dan nilai Z-Score variabel Dosen terhadap Stres adalah $<1,96$. 
Dengan demikian terdapat keterkaitan yang signifikan antara variabel Keluarga terhadap Stres. H0.6 ditolak dan H1.6 diterima. Artinya faktor keluarga berpengaruh secara positif terhadap stres mahasiswa dalam mengerjakan Tugas Akhir dengan berlawanan arah. Semakin keluarga mendukung maka stres mahasiswa semakin berkurang. Besarnya pengaruh faktor keluarga terhadap stres adalah hanya sebesar 0,25 atau sebesar $25 \%$.

Dari hasil estimasi yang telah dilakukan diketahui bahwa nilai ZScore variabel Dosen terhadap Stres adalah $<1,96$, dan bernilai negatif. Dengan demikian tidak ada keterkaitan yang signifikan antara variable Dosen terhadap Stres. Dengan demikian H0.7 diterima dan $\mathrm{H} 1.7$ ditolak. Hal ini juga berarti faktor dosen tidak berpengaruh secara positif terhadap stres mahasiswa dalam mengerjakan Tugas Akhir. Besarnya pengaruh faktor dosen terhadap stres mahasiswa adalah sebesar 0,06 atau sebesar $6 \%$.

Hal ini berarti, 1) tidak ada keterkaitan yang signifikan antara variabel Sosial terhadap Stres, 2) tidak ada keterkaitan yang signifikan antara variabel Sosial terhadap Stres; terdapat keterkaitan yang signifikan antara variabel Keluarga terhadap Stres.; dan tidak ada keterkaitan yang signifikan antara variabel Dosen terhadap Stres. Dengan demikian $\mathrm{H}_{0.4}$ diterima dan $\mathrm{H}_{1.4}$ ditolak; $\mathrm{H}_{0.5}$ diterima dan $\mathrm{H}_{1.5}$ ditolak; $\mathrm{H}_{0.6}$ ditolak dan $\mathrm{H}_{1.6}$ diterima; dan $\mathrm{H}_{0.7}$ diterima dan $\mathrm{H}_{1.7}$ ditolak.

\section{c. Hubungan Kausal antar Variabel}

Hubungan kausal antar variabel yang akan memperlihatkan bagaimana setiap variabel akan efek kontribusi baik langsung maupun tidak langsung. Rangkuman kontribusi langsung dan kontribusi tidak langsung antar variabel dalam penelitian ini disampaikan pada Tabel 6 berikut.

Tabel 6 Kontribusi Variabel

\begin{tabular}{lccc}
\hline \multirow{2}{*}{ Variabel } & \multicolumn{3}{c}{ Efek } \\
\cline { 2 - 4 } & Langsung & Tak Langsung & Total \\
\hline Sosial terhadap Motivasi $(\mathrm{X} 1 \rightarrow \mathrm{Y}$ 1) & 0,11 & 0 & 0,11 \\
\hline Keluarga terhadap Motivasi $(\mathrm{X} 2 \rightarrow \mathrm{Y} 1)$ & 0,43 & 0 & 0,43 \\
\hline Dosen terhadap Motivasi $(\mathrm{X} 3 \rightarrow \mathrm{Y} 1)$ & 0,18 & 0 & 0,18 \\
\hline Motivasi terhadap Stres $(\mathrm{Y} 1 \rightarrow \mathrm{Y} 2)$ & 0,02 & 0 & 0,02 \\
\hline Sosial terhadap Stres $(\mathrm{X} 1 \rightarrow \mathrm{Y} 2)$ & 0,06 & 0 & 0,06 \\
\hline Keluarga terhadap Stres $(\mathrm{X} 2 \rightarrow \mathrm{Y} 2)$ & $-0,25$ & 0 & $-0,25$ \\
\hline Dosen terhadap Stres $(\mathrm{X} 3 \rightarrow \mathrm{Y} 2)$ & $-0,06$ & 0 & $-0,06$ \\
\hline Sosial, Motivasi trhadap Stres $(\mathrm{X} 1 \rightarrow \mathrm{Y} 1 \rightarrow \mathrm{Y} 2)$ & 0 & 0,002 & 0,002 \\
\hline Keluarga, Motivasi thadp Stres $(\mathrm{X} 2 \rightarrow \mathrm{Y} 1 \rightarrow \mathrm{Y} 2)$ & 0 & 0,009 & 0,009 \\
\hline Dosen, Motivasi terhadp Stres $(\mathrm{X} 3 \rightarrow \mathrm{Y} 1 \rightarrow \mathrm{Y} 2)$ & 0 & 0,004 & 0,004 \\
\hline
\end{tabular}

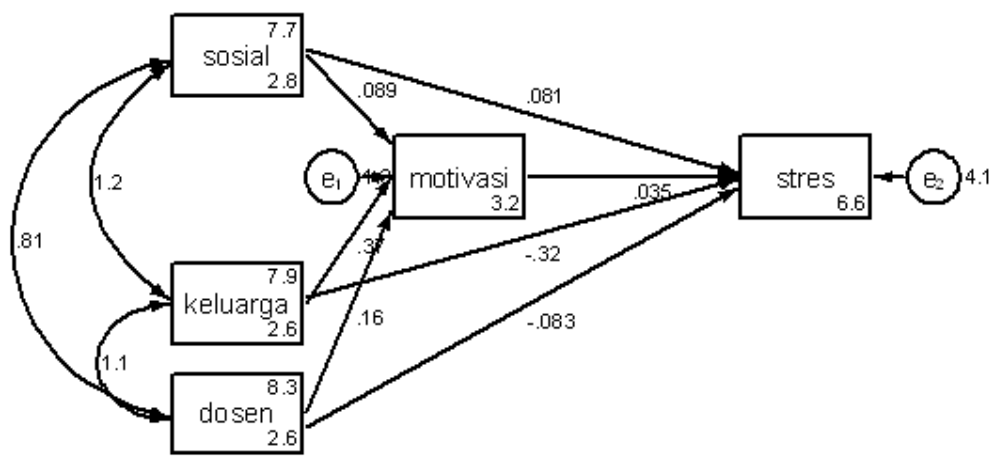

Gambar 2 Hubungan Kausal antar Variabel

JAS-PT

JURNAL ANALISIS SISTEM PENDIDIKAN TINGG ISSN $2580-5339$ eISSN $2620-5718$

Volume 5

Nomor 1

JULI 2021

Hal 65 - 74

DOSEN INDONESIA SEMESTA 
Motivasi merupakan suatu kekuatan yang dapat mendorong seseorang melakukan sesuatu. Dalam penelitian ini, secara bersama-sama faktor sosial, faktor keluarga, dan faktor dosen menyumbang $34 \%$ perubahan motivasi. Nilai Prob > F yang lebih kecil dari 0,05 menyatakan bahwa faktor sosial, keluarga, dan dosen, secara bersama-sama memberikan pengaruh yang signifikan terhadap motivasi Akan tetapi, dari ketiga faktor tersebut, secara parsial, faktor keluarga dan faktor dosen secara positif berpengaruh terhadap motivasi mahasiswa, sementara faktor sosial dinyatakan tidak memiliki pengaruh.

Meskipun $84,88 \%$ mahasiswa menyatakan bahwa mereka suka untuk berkumpul dengan teman-temannya serta melakukan diskusi, akan tetapi ternyata hal ini tidak membuat mahasiswa merasa termotivasi dalam menyelesaikan Tugas Akhirnya. Hal ini senada dengan temuan Li et.al (2012), yang juga menyampaikan bahwa hubungan antara hubungan sosial dan motivasi akademik adalah tidak signifikan. Dikatakan bahwa hubungan sosial hanya bermanfaat untuk memberikan motivasi akademik pada wanita, sementara secara gabungan laki-laki dan wanita, tidaklah signifikan. Di dalam penelitian ini, $79 \%$ responden adalah laki-laki. Dengan demikian temuan ini mendukung apa yang disampaikan oleh peneliti sebelumnya bahwa stres yang dialami oleh mahasiswa tidak membedakan gender atau dengan kata lain semua merasakan tekanan saat menyelesaikan tugas akhirnya.

Penelitian ini juga menemukan bahwa faktor sosial juga dinyatakan tidak memiliki pengaruh terhadap stres mahasiswa dalam mengerjakan Tugas Akhir. Hal ini berbeda dengan teori dan penelitian tentang hubungan sosial yang menunjukkan bahwa kesejahteraan, perilaku dan motivasi seseorang dapat dipengaruhi oleh hubungan sosial seseorang (Anderman \& Anderman, 1999; Buhs \& Ladd, 2001; Schmitz \& Crystal, 2000) juga membuktikan bahwa hubungan sosial positif penting dalam peningkatan motivasi akademik.Perbedaan temuan ini bisa terjadi karena selama ini sebagian besar mahasiswa tidak merasa bersaing dan menyadari bahwa masalah yang melanda temantemannya dalam proses penyelesaian Tugas Akhir adalah masalah individu yang bisa sama atau mungkin berbeda dengan yang dialaminya. Karenanya, apabila temantemannya lebih dahulu mampu menyelesaikan Tugas Akhir dianggap sebagai kewajaran dan bukan sebagai persaingan.

Berbeda dengan faktor sosial, faktor keluarga memberikan pengaruh yang positif signifikan pada motivasi karyawan. $83,3 \%$ responden menyampaikan bahwa keluarga adalah faktor penting yang mendukung penyelesaian Tugas Akhir. Faktor motivasi yang disebabkan oleh keluarga juga berkaitan secara positif signifikan dan berbeda arah dengan stres mahasiswa. Artinya, dukungan yang diperoleh dari keluarga seperti dukungan dari orang tua, adanya fasilitas belajar yang diberikan di rumah, dan suasana nyaman di rumah membuat mahasiswa menjadi termotivasi untk menyelesaikan Tugas Akhir. Semakin termotivasi, maka mahasiswa menjadi tidak stres. Demikian pula sebaliknya, semakin tidak termotivasi maka stres mahasiswa juga akan meningkat.

Faktor dosen juga disampaikan memberikan pengaruh yang positif signifikan terhadap motivasi mahasiswa dalam menyelesaikan Tugas Akhirnya. Meskipun tidak memiliki pengaruh sebesar faktor keluarga, dorongan yang berikan oleh dosen wali saat proses pembimbingan Tugas Akhir disampaikan memberikan kekuatan pada mahasiswa. Hal ini karena dosen pembimbing sangat memahami bagaimana proses pembelajaran yang telah dilalui oleh mahasiswa dan dapat memberikan contoh-contoh dari pengalaman pembimbingan dengan mahasiswa lainnya. Meskipun mempengaruhi motivasi mahasiswa, tetapi faktor dosen pembimbing dinyatakan tidak mempengaruhi stres mahasiswa. Hal ini bisa terjadi juga karena mahasiswa dapat memilih sendiri dosen 
pembimbing yang diingini selama dosen pembimbing tersebut masih belum terpenuhi kuota bimbingannya. Dengan memilih sendiri diharapkan mahasiswa akan mudah dan nyaman untuk berkomunikasi dengan dosen yang pada akhirnya akan memudahkan mereka untuk menyusun Tugas Akhir.

Motivasi yang dimiliki oleh mahasiswa yang sedang menyusun Tugas Akhir juga dinyatakan tidak mempengaruhi stres. Hasil yang sama juga ditunjukkan dalam penelitian yang telah dilakukan oleh Hunter et,al (2018). Dalam penelitian yang mengambil sampel 100 mahasiswa tersebut menyimpulkan bahwa motivasi tidak memiliki dampak signifikan pada hubungan antara stres akademik dan kepuasan hidup.

\section{PENUTUP}

Berdasarkan hasil pengujian dan pembahasan yang telah dilakukan maka dapat disimpulkan bahwa faktor sosial, keluarga, dosen, dan motivasi secara langsung tidak memiliki pengaruh terhadap stres mahasiswa yang sedang dalam menyusun Tugas Akhir. Sedangkan untuk faktor motivasi, meskipun Keluarga dan dosen menjadi faktor yang secara signifikan mempengaruhi motivasi mahasiswa, tetapi hanya faktor keluarga yang memberikan pengaruh terhadap stres mahasiswa. Dukungan keluarga memberikan dorongan atau motivasi dan semakin termotivasi maka tingkat stres mahasiswa akan menurun.

\section{DAFTAR PUSTAKA}

Anderman, L. H., \& Anderman, E. M. (1999). Social Predictors of Changes in Students' Achievement Goal Orientations. Contemporary Educational Psychology, 24(1), $21-$ 37. https://doi.org/10.1006/ceps.1998.0978

Ang, R. P., \& Huan, V. S. (2006). Relationship between Academic Stress and Suicidal Ideation: Testing for Depression as a Mediator Using Multiple Regression. Child Psychiatry and Human Development, 37(2), 133-143. https://doi.org/10.1007/s10578-006-0023-8

Anoraga, P. (2006). Psikologi Kerja. Rineka Cipta.

Bennett, T. H., \& Holloway, K. R. (2014). Drug Misuse Among University Students in the UK: Implications for Prevention. Substance Use \& Misuse, 49(4), 448-455. https://doi.org/10.3109/10826084.2013.846378

Biron C, Brun JP, I. H. (2008). Extent and sources of occupational stress in university staff. Work, 30(4). https://www.ncbi.nlm.nih.gov/pubmed/18725713

Buhs, E. S., \& Ladd, G. W. (2001). Peer rejection as antecedent of young children's school adjustment: An examination of mediating processes. Developmental Psychology, 37(4), 550-560. https://doi.org/10.1037/0012-1649.37.4.550

Busari, A. (2012). Evaluating the Relationship between Gender, Age, Depression and Academic Performance among Adolescents. Scholarly Journal of Education, 1, 612.

https://www.researchgate.net/publication/267824240_Evaluating_the_Relationshi p_between_Gender_Age_Depression_and_Academic_Performance_among_Adol escents

Chernomas, W. M., \& Shapiro, C. (2013). Stress, Depression, and Anxiety among Undergraduate Nursing Students. International Journal of Nursing Education Scholarship, 10(1). https://doi.org/10.1515/ijnes-2012-0032

Dada, J. O., Babatunde, S. O., \& Adeleye, R. O. (2019). Assessment of academic stress and coping strategies among built environment undergraduate students in Nigerian

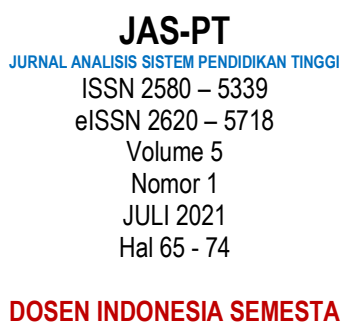

DOSEN INDONESIA SEMESTA 
higher education. Journal of Applied Research in Higher Education, 11(3), 367378. https://doi.org/https://doi.org/10.1108/JARHE-06-2018-0100

Deb, S., Strodl, E., \& Sun, J. (2015). Academic Stress, Parental Pressure, Anxiety and Mental Health among Indian High School Students. International Journal of Psychology and Behavioral Sciences, 5(1), 26-34. https://doi.org/10.5923/j.ijpbs.20150501.04

Enderlein, G. (1994). Retherford, Robert D., Choe, Minja Kim: Statistical Models for Causal Analysis. John Wiley \&amp; Sons, New York - Chichester - Brisbane Toronto - Singapore 1993. 258 S., £32.95. Biometrical Journal, 36(8), 962-962. https://doi.org/10.1002/bimj.4710360809

Goff, A.-M. (2011). Stressors, Academic Performance, and Learned Resourcefulness in Baccalaureate Nursing Students. International Journal of Nursing Education Scholarship, 8(1). https://doi.org/10.2202/1548-923X.2114

Gunawati, R., Hartati, S., \& Listiara, A. (2010). Hubungan antara Efektivitas Komunikasi Mahasiswa-Dosen Pembimbing Utama Skripsi dengan Stres dalam Menyusun Skripsi pada Mahasiswa Program Studi Psikologi Fakultas Kedokteran Universitas $\begin{array}{llll}\text { Diponegoro. Jurnal } & \text { Psikologi, }\end{array}$ https://doi.org/https://doi.org/10.14710/jpu.3.2.93 - 115

Jimenez, C., Navia-Osorio, P. M., \& Diaz, C. V. (2010). Stress and health in novice and experienced nursing students. Journal of Advanced Nursing, 66(2), 442-455. https://doi.org/10.1111/j.1365-2648.2009.05183.x

Kumar, B., Shah, M. A. A., Kumari, R., Kumar, A., Kumar, J., \& Tahir, A. (2019). Depression, Anxiety, and Stress Among Final-year Medical Students. Cureus. https://doi.org/10.7759/cureus.4257

Kupriyanov, R., \& Zhdanov, R. (2014). The Eustress Concept: Problems and Outlooks. World Journal of Medical Sciences, 11(2), 179-185. https://doi.org/10.5829/idosi.wjms.2014.11.2.8433

Moscaritolo, L. M. (2009). Interventional Strategies to Decrease Nursing Student Anxiety in the Clinical Learning Environment. Journal of Nursing Education, 48(1), 17-23. https://doi.org/10.3928/01484834-20090101-08

Saha, D. (2017, April 6). A Student Commits Suicide Every Hour In India. IndiaSpend. https://archive.indiaspend.com/special-reports/a-student-commits-suicide-everyhour-in-india-3-85917

Schmitz, M. F., \& Crystal, S. (2000). Social Relations, Coping, and Psychological Distress Among Persons With HIVIAIDS1. Journal of Applied Social Psychology, 30(4), 665-685. https://doi.org/10.1111/j.1559-1816.2000.tb02818.x

Subramani, C., \& Venkatachalam, J. (2019). Parental Expectations and Its Relation to Academic Stress among School Students. International Journal of Research and $\begin{array}{llll}\text { Analytical } & \text { Reviews } & \text { (IJRAR), } & \text { 95-99. }\end{array}$ http://www.ijrar.org/viewfull.php?\&p_id=|JRAR19L1016

The American College Health Association. (2009). American College Health AssociationNational College Health Assessment Spring 2008 Reference Group Data Report (Abridged). JOURNAL OF AMERICAN COLLEGE HEALTH, 57(5), 477-488.

JAS-PT

ISSN $2580-5339$ eISSN $2620-5718$ Volume 5

Nomor 1

JULI 2021

Hal 65 - 74 https://www.acha.org/documents/ncha/JACH_March_2009_SP08_Ref_Grp.pdf

Uchil, H. B. (2017). The Effect of Stress on Students' Performance. Stress Management Professional An International Journal, 5(1), 16-21. http://www.smpij.org/images/45117a.pdf 